\title{
SCHOOL MOTIVATION AND ACHIEVEMENT OF STUDENTS IN SECONDARY EDUCATION
}

\author{
Francisco Manuel Morales Rodríguez \\ University of Malaga, Spain \\ E-mail: framorrod@uma.es
}

\begin{abstract}
This paper aims to analyse the importance of intrinsic motivation factors as determinants of academic achievement in English as a Foreign Language (EFL). The general aim of the present study has been to analyse the existing relationship between students'academic motivation and performance. This paper explores the importance of motivational variables for school achievement. In particular, the present study suggests that students with a higher intrinsic motivation to learn English will achieve better grades in this subject. Participants were 542 students (male and female) of Secondary Education. Results show that there is a correlation between academic goals and academic results; in particular an association exists between learning goals (intrinsic motivation) and a high academic achievement. With regards to the importance of intrinsic motivational factors, this study concludes that these factors are determinants of academic achievement in English as a Foreign Language (EFL). Therefore, results are useful in view of improving the process of teaching/learning EFL. The relevant conclusion reached here point to the academic goals as being indicator of and decisive factor for academic achievement.
\end{abstract}

Key words: academic achievement, academic goals, academic motivation, English as a foreign language.

\section{Introduction}

From a constructivist approach (Shunk, 2000; Wolters, 2004), school learning cannot exclusively be reduced to students' cognitive level. We must also take into account motivational aspects such as learners' intentions, goals, perceptions and beliefs, as we understand that these aspects are mental representations showing associations between cognitive aspects and affective-motivational aspects in school learning. In fact, a number of research studies have found that academic learning has deep repercussions on a student's inner world, that is to say, that students' expectations, attributions, motives and interests determine their school success or failure (Ames, 1992; Ames and Archer, 1988, De la Fuente, 2012). The area of school motivation is a complex one; there are a number of definitions and theories that attempt to explain the processes and outcomes of school learning, especially in relation to the study of academic subjects. The present study focuses on the field of English as a Foreign Language (EFL). It has often been said that any learning model involves, either explicitly or implicitly, a theory of motivation. An established definition of motivation is the "set of processes involved in the activation, direction and persistence of behaviour" (Pekrun, 1992). This definition somehow emphasizes the cognitive component and dynamic nature of the motivation construct. In this vein, some authors believe that academic motivation explains the stimulation, direction and persistence of a particular behaviour towards a specific academic goal which is focused on learning, performance, the Self, social approval and/or avoidance of challenging tasks (Dweck and Leggett, 1988). It is known that there are many factors guiding student behaviour in the academic context. Such factors include: a) Situational factors (which refer to the teaching-learning process, teacher, 
OF PSYCHOLOGY

IN THE $21^{\text {st }}$ CENTURY Volume 4, 2012

40

subject content, type of interaction, assessment method, etc.); and b) Student-centred factors (which refer to mental representations, goals, beliefs, attributions, theories; attitudes, interests, expectations, self-perceptions, social and developmental factors, as well as factors resulting from individual differences).

\section{Theories}

With the purpose of using an integrative approach, different theories are here examined, not individually and without connection, but rather explaining their role in relation to the processes of academic motivation. Thus, Pintrich and DeGroot (1990) identified three relevant dimensions in the area of motivation in educational contexts: a) expectancy components, b) value components and c) affective components. Expectancy components refer to students' expectations about their success in performing a task; while value components concern students' goals and beliefs about the importance of performing the task. Different types of goal orientation have been described in this area. Among them, learning goals have been widely studied. According to the representative authors of the goals approach (Ames, 1992; Elliot and Dweck, 1988; Nicholls, 1984; Pintrich, 2000b), students with learning goals seek to perform a task in order to acquire new knowledge and improve their competence. In this light, they are likely to believe that their effort leads to their success/failure and that intelligence is a modifiable variable. They are also more likely to see difficult tasks as a challenge, and use deep processing strategies. On the other hand, students with performance goals seek to demonstrate their competence in order to receive favourable judgments and avoid negative judgments. They are less concerned with learning per se but as a means to demonstrate their competence. They see intelligence as a fixed and constant concept and difficult problems as potential failure situations. Also, they are likely to use low-complexity strategies. Pintrich and DeGroot (1990) suggest three types of goals: self-oriented goals, socially oriented goals and work-avoidance goals. They also talk about the subjective value of the task: importance, usefulness, interests; and an affective component concerning students' emotional reactions to the task and to task results. It is worth stressing that recent views have suggested that self-concept plays an important role in motivation and school learning. In fact, the most recent theories on motivation contemplate self-concept as a first order element to be taken into account (González-Pienda, González-Cabanach, Núñez and Valle, 2002).

\section{Types of Goals}

The present research study identifies the following four types of goals (see Table 1), which have been used in established studies on motivation and were introduced by Núñez, González-Pineda, González-Pumariega, García and Roces (1997):

1. Learning goals involve achievement motivation, curiosity, perception of the task as a challenge and interest to learn (intrinsic motivation). Students with learning motivation are willing to persist in the face of difficulty because they are interested in acquiring new knowledge, and they assume the risk of making mistakes.

2. Performance goals are oriented to the achievement of external goals, such as quest rewards, favourable judgments, teachers' approval and avoidance of negative judgments (extrinsic motivation). Students with performance motivation prefer to receive a positive assessment on an easy task, rather than assuming the risk of receiving a negative assessment, on a more challenging and meaningful task (Dweck and Leggett, 1988). While learning goals involve a mastery-oriented pattern, performance goals involve a higher risk of showing what is called a helpless pattern (Elliott and Dweck, 1988). Performance goals lead students to try and defend themselves to others and to question their ability, thus avoiding challenging tasks, albeit reducing their chances of acquiring knowledge and improving their abilities.

3. Socially oriented goals aim to achieve good results in order to reinforce social image. These Students become frustrated with poor results.

4. Lack of goals (reward-oriented goals). There are also students with no academic goals 
who seek to avoid the task. These are often students conditioned by generalized failures who feel only motivated by the reward.

Table 1. Types of Goal (Núñez et al., 1997; González-Pineda et al., 2002).

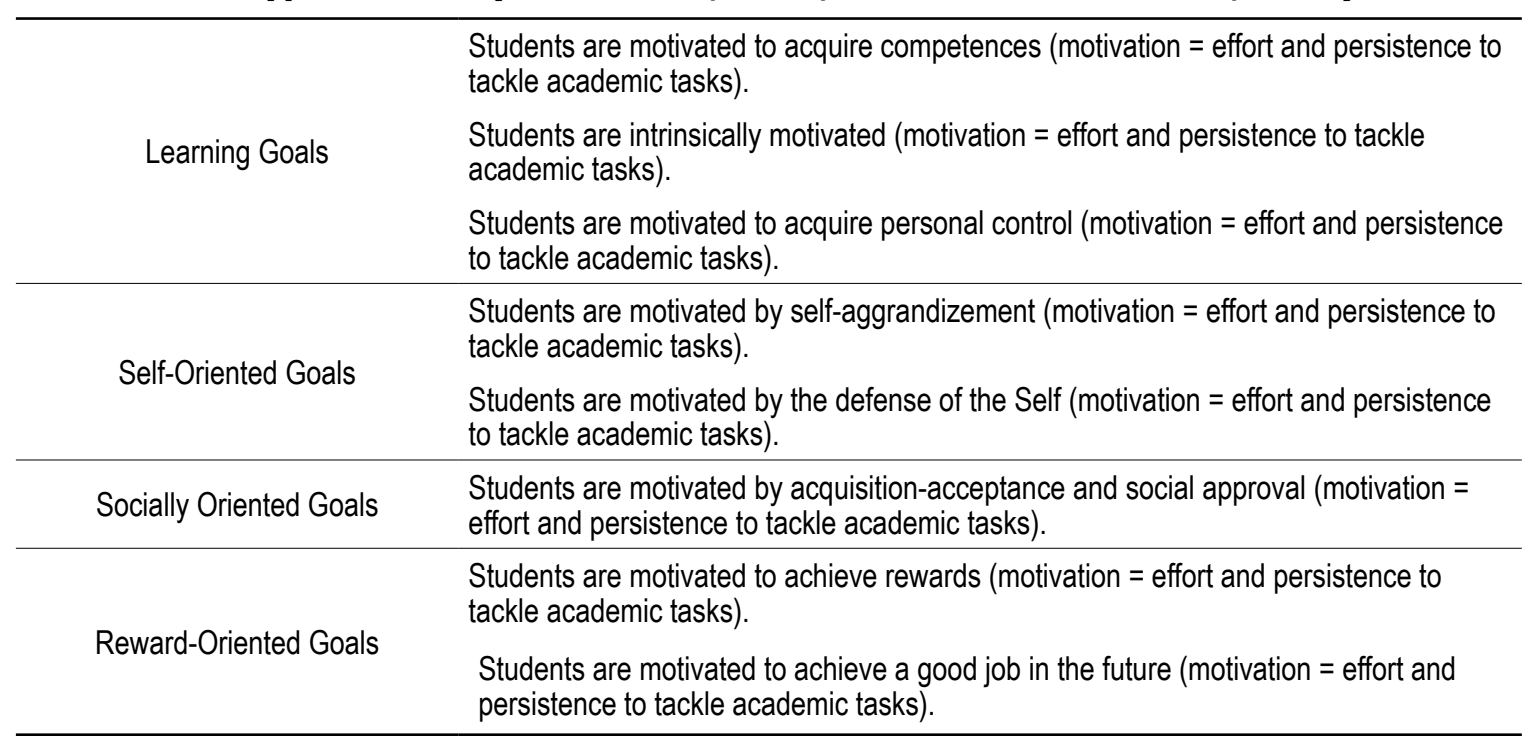

As observed in Table 1, some research studies (González-Pineda et al., 2002; Wolters, 2004), found that there is one particular type of student whose primary objective is to maintain or increase their self-esteem in comparison to others, hence opting for self-assessment goals or self-oriented goals or self-focused goals. These students usually tackle their academic tasks by asking themselves whether or not they are able to perform them correctly. If they think they have a good chance of successfully performing the task, they commit to it with enthusiasm and without anxiety. However, if they think that they will struggle to perform the task successfully, regardless of the reason, they struggle to find the appropriate strategies and to implement them. Furthermore, they feel tense and irritable as soon as an obstacle appears. This occurs because these students anticipate that, in the event of failure, their lack of capacity will show, which may have an effect on their self-esteem. As a consequence, students in this case tend to use a number of strategies leading to the defense of "the Self" (García and Pintrich, 1994) and misconduct, such as cheating.

\section{Problem of Research}

Currently there are a number of research studies stressing the role of intrinsic motivation in academic learning in general, and in foreign language learning in particular. This is because the adjustment and optimal development of the foreign language learning/teaching process require effort, persistence and self-perceived competences. The present study analyses the importance of intrinsic motivational factors as determinants of academic performance in EFL. The general aim of the present study has been to analyse the existing relationship between "students' academic motivation" and "students' academic performance" variables.

\section{Methodology of Research}

\section{General Background of Research}

In particular, this study tested the hypothesis that students with a higher intrinsic motivation to learn EFL would achieve better grades in this subject. In other words, students with self-oriented goals or learning goals would achieve a high academic performance (i.e. good results) in EFL, as both these goals involve task control satisfaction and performing the task with high levels of efficacy, interest, positive affection, persistence, learning strategies and a good performance. 
OF PSYCHOLOGY

IN THE $21^{\text {st }}$ CENTURY Volume 4, 2012

\section{Sample of Research}

Participants were 542 students of Secondary Education ( $3^{\text {rd }}$ and $4^{\text {th }}$ grade, i.e. 14 to 16 year-olds) from three high schools in the city of Malaga. Two different groups were administered the questionnaire and assessed in relation to their performance. The groups selected came from two different socio-cultural levels (medium-high and medium-low), with the purpose of obtaining a sample as representative as possible. It is worth mentioning that the sample was gender-balanced, as 307 of the respondents were girls (56.64\%) and 235 boys (43.35\%). Most participants were aged between 14 and 16 years old.

\section{Instrument and Procedures}

There are different tests to assess the "learning goals" variable. The present study has used the Questionnaire to Assess Academic Goals in Secondary Education Students (CEMA-2 in Spanish) (Núñez, González-Pienda, González-Pumariega, García and Roces, 1997). The questionnaire identifies the types of goals mentioned earlier (see Table 1), i.e. learning goals, reward-oriented goals, selforiented goals and socially oriented goals. The above authors believe that it is important to distinguish the nature of the rewards that motivate the individual. Thus, the category "performance goals" must be considered in two separate dimensions: performance goals related to social value (e.g. "I study because I want to be valued by my parents and teachers") and performance goals related to obtaining tangible rewards (e.g. "I study because I want to get a good job in the future). The questionnaire is composed of 42 items with a Likert-type scale for responses, where students assess their motivation to study hard, based on a 0 to 5 scale ( $1=$ Never; $5=$ Always). The scale allows for the extraction of the type of motivation that leads students to tackle their tasks in the EFL subject. What follows is, an example of an item from each category of the questionnaire:

1. An item assessing the goal of studying to acquire competence and control is: "I study hard because the new knowledge allows me to be more competent."

2. An item assessing the goal of studying to defend the Self (performance-avoidance goals) is: "I study hard because I do not want my classmates to make fun of me."

3. An item assessing the goal of studying because of an individual interest in the subject matter is: "I study hard because I find what I study very interesting."

4. An item assessing the work-avoidance goal to defend the Self is: "I avoid working in class if I think that I will do worse than everyone else."

5. An item assessing the goal of studying to seek self-aggrandizement (performanceapproach goals) is: "I study hard because I want to get one of the best student grades in my class."

6. An item assessing the goal of studying to acquire social value is: "I study hard because I want the people I care for to be proud of me."

7. An item assessing the goal of studying to get a good job in the future is: "I study hard because I want to get a good job in the future."

8. An item assessing the goal of studying to avoid punishment is: "I study hard because I want to avoid the punishment that I would receive if I do not get good results."

This instrument presents appropriate psychometric properties. The reliability indices (Cronbach's alpha coefficients) for each factor/strategy assessed in the sample ranged from 0.75 to 0.82 .

To assess academic performance, students' grades in the subject of EFL were considered. The performance assessment scale ranged from 1 to 10 (average performance in EFL according to official records). This study analysed the afore-mentioned variables by comparing the following three groups:

(1) The average of grades in EFL ranging from 0 to 5.

(2) The average of grades in EFL ranging from 5 to 7.

(3) The average of grades in EFL ranging from 7 to 10. 
In sum, the present study used, on the one hand, questionnaires as the instrument to assess motivation; and on the other, students' grades in EFL to assess academic performance. Consequently, the two variables evaluated were (1) motivation and (2) academic performance.

The two Secondary Education High Schools were contacted and informed in writing of the objectives of the project. Likewise, parents were asked for their permission and consent, and were given the corresponding instructions and information. Questionnaires were conducted by two researchers trained to explain the objectives to teachers and give instructions to students. Questionnaires were completed in a collective application in the different Secondary Education classrooms. Before handing out the questionnaires, students were informed that the data they provided would be confidential and that their full name was only required in order to compare their questionnaire results with their academic record. Additionally, they were given unlimited time to complete the questionnaires.

\section{Data Analysis}

Data coding and analysis were conducted by using the SPSS 15.0 statistical package. The study has conducted descriptive analyses to reflect percentages, means and standard deviations. Additionally, the Student's t-test was applied on independent samples to find out if there were statistically significant differences in goals based on academic performance.

\section{Results of Research}

The average score in the "academic goals" variable was extracted from the 542 secondary school students in the sample, as observed in Table 2:

Table 2. Average and Typical Deviations in the "Goals" Variable in the Sample.

\section{SAMPLE AVERAGE}

\section{LEARNING GOALS}

1. Acquiring competence and control. $3.59(.93)$

2. Interest in the subject (intrinsic motivation).

\section{SELF-ORIENTED GOALS}

3. Defense of the Self by personal involvement (promoting motivation).

4. Defense of the Self by lack of involvement (motivational inhibition).

5. Self-aggrandizement (by involvement).

6. Acquiring social value by getting approval or by avoiding rejection ACHIEVEMENT GOALS OR REWARD-ORIENTED GOALS

7. Getting a good job in the future. $4.52(.41)$

8. Avoiding punishment (or loss of privileges). $2.53(1.46)$

The profile of the studied sample is characterized by the predominance of learning goals as well as reward-oriented goals (see Table 2). In other words, participating secondary education students study EFL either, because they like the subject per se (hence they seek to improve their competence, i.e. they are intrinsically motivated), or because they seek to get a good job in the future (hence they seek a reward-oriented goal, i.e. they are extrinsically motivated). Therefore, participating students would study EFL not only because they are interested in the subject (intrinsic motivation) and their subsequent satisfaction, but also because of the reward that they would get (to find a good job). 
OF PSYCHOLOGY

IN THE $21^{\text {st }}$ CENTURY Volume 4, 2012

\section{Assessment of the Motivational Components (Goals) and Academic Performance}

The present study analysed the correlation between secondary education students' motivation and their academic achievement. In order to assess performance, the study has used all students' grades in the common subject of English as a Foreign Language. The overall average performance was set according to a scale of 1 to 10 (from poor to outstanding). While the former variable (motivation) has been examined by means of questionnaires; the latter (performance) was examined by means of students' grades in EFL. Grades were classified into the following three groups in view of the motivation-performance comparison: [0 to 5], [5 to 7] and [7 to 10]. The average was extracted from each group, as observed in the following tables:

Table 3. Mean Scores on Learning Goals Based on the Grade (0-10) Obtained in EFL.

\begin{tabular}{|c|c|c|c|}
\hline \multirow[b]{2}{*}{ ACADEMIC GOALS } & \multicolumn{3}{|c|}{ ACADEMIC GRADE } \\
\hline & $\begin{array}{l}\text { Less than } \\
\quad 5\end{array}$ & $\begin{array}{l}\text { Between } 5 \\
\text { and } 7\end{array}$ & $\begin{array}{l}\text { Between } \\
7 \text { and } 10\end{array}$ \\
\hline LEARNING GOALS & Average & Average & Average \\
\hline 1. Acquiring competence and control. & 2.72 & 3.22 & 4.68 \\
\hline 2. Interest in the subject (intrinsic motivation). & 1.40 & 1.66 & 3.62 \\
\hline \multicolumn{4}{|l|}{ SELF-ORIENTED GOALS } \\
\hline 3. Defense of the Self by personal involvement (promoting motivation). & 1.82 & 2.54 & 4.24 \\
\hline 4. Defense of the Self by lack of involvement (motivational inhibition). & 3.55 & 2.13 & 1.18 \\
\hline 5. Self-aggrandizement (by involvement). & 2.33 & 2.56 & 3.05 \\
\hline \multicolumn{4}{|l|}{ SOCIALLY ORIENTED GOALS } \\
\hline $\begin{array}{l}\text { 6. Acquiring social value by getting approval or by avoiding rejection } \\
\text { (involvement). }\end{array}$ & 3.85 & 2.25 & 1.22 \\
\hline \multicolumn{4}{|l|}{ ACHIEVEMENT GOALS OR REWARD-ORIENTED GOALS } \\
\hline 7. Getting a good job in the future. & 4.81 & 3.78 & 4.64 \\
\hline 8. Avoiding punishment (or loss of privileges). & 4.23 & 2.14 & 1.04 \\
\hline
\end{tabular}

Table 4. Mean Difference in the Motivation Variable (Learning Goals) Based on the Performance Variable (Grades 0 to 5).

$g \mathrm{l}=540$

\begin{tabular}{llcc}
\hline \multicolumn{1}{c}{ Goals } & $\begin{array}{c}\text { Average Grades } \\
\text { Less than 5* (SD) }\end{array}$ & $\begin{array}{c}\text { Averages Grades } \\
\text { Between 5 and 7** (SD) }\end{array}$ & t \\
\hline \multicolumn{1}{c}{ Learning Goals } & & $3.22(.72)$ & $-3.56^{*}$ \\
$\begin{array}{l}\text { 1. Acquiring competence and control. } \\
\text { 2. Interest in the subject (intrinsic motivation). }\end{array}$ & $1.40(.19)$ & $1.66(.23)$ & $-2.55^{* *}$ \\
$\begin{array}{l}\text { Self-Oriented Goals } \\
\text { 3. Defense of the Self by personal } \\
\text { involvement (promoting motivation). }\end{array}$ & $1.82(.81)$ & $2.54(.80)$ & $-13.56^{*}$ \\
$\begin{array}{l}\text { 4. Defense of the Self by lack of involvement } \\
\text { (motivational inhibition). }\end{array}$ & $3.55(.85)$ & $2.13(.82)$ & $19.37^{*}$ \\
5. Self-aggrandizement (by involvement). & $2.33(.48)$ & $2.56(.19)$ & $-4.04^{*}$
\end{tabular}




\begin{tabular}{|c|c|c|c|}
\hline & & & $g \mathrm{~g}=\mathbf{5 4 0}$ \\
\hline Goals & $\begin{array}{l}\text { Average Grades } \\
\text { Less than } 5^{*}(S D)\end{array}$ & $\begin{array}{c}\text { Averages Grades } \\
\text { Between } 5 \text { and } 7^{* *}(\mathrm{SD})\end{array}$ & $\mathbf{t}$ \\
\hline \multicolumn{4}{|l|}{ Socially-Oriented Goals } \\
\hline $\begin{array}{l}\text { 6. Acquiring social value by getting approval } \\
\text { or by avoiding rejection (involvement). }\end{array}$ & $3.85(.63)$ & $2.25(.69)$ & $21.58^{*}$ \\
\hline \multicolumn{4}{|l|}{$\begin{array}{l}\text { Achievement Goals or Reward-Oriented } \\
\text { Goals }\end{array}$} \\
\hline 7. Getting a good job in the future. & $4.81(.67)$ & $3.78(.70)$ & $17.97^{*}$ \\
\hline $\begin{array}{l}\text { 8. Avoiding punishment (or loss of } \\
\text { privileges). }\end{array}$ & $4.23(.52)$ & $2.14(.41)$ & $20.4^{*}$ \\
\hline
\end{tabular}

Statistical Significance. ${ }^{*} p<0.05 ;{ }^{* *} p<0.0$

Table 5. Mean Difference in the Motivation Variable (Learning Goals) Based on the Performance Variable (Grades 5 to 7).

$g l=540$

\begin{tabular}{|c|c|c|c|}
\hline Goals & $\begin{array}{l}\text { Average Grades } \\
\text { Less than } 5^{*}(S D)\end{array}$ & $\begin{array}{l}\text { Average Grades Between } \\
7 \text { and } 10^{* *}(S D)\end{array}$ & $t$ \\
\hline \multicolumn{4}{|l|}{ Learning Goals } \\
\hline $\begin{array}{l}\text { 1. Acquiring competence } \\
\text { and control. }\end{array}$ & $2.72(.91)$ & $4.68(.81)$ & $-17.80^{*}$ \\
\hline $\begin{array}{l}\text { 2. Interest in the subject } \\
\text { (intrinsic motivation). }\end{array}$ & $1.40(.19)$ & $3.62(.44)$ & $-26.66^{*}$ \\
\hline \multicolumn{4}{|l|}{ Self-Oriented Goals } \\
\hline $\begin{array}{l}\text { 3. Defense of the Self } \\
\text { by personal involvement } \\
\text { (promoting motivation). }\end{array}$ & $1.82(.81)$ & $4.24(.91)$ & $-29.46^{*}$ \\
\hline $\begin{array}{l}\text { 4. Defense of the Self } \\
\text { by lack of involvement } \\
\text { (motivational inhibition). }\end{array}$ & $3.55(.85)$ & $1.18(.89)$ & $31.61^{*}$ \\
\hline $\begin{array}{l}\text { 5. Self-aggrandizement (by } \\
\text { involvement). }\end{array}$ & $2.33(.48)$ & $3.05(.61)$ & $-8.60^{*}$ \\
\hline \multicolumn{4}{|l|}{ Socially-Oriented Goals } \\
\hline $\begin{array}{l}\text { 6. Acquiring social value } \\
\text { by getting approval or by } \\
\text { avoiding rejection. }\end{array}$ & $3.85(.63)$ & $1.22(.71)$ & $34.42^{*}$ \\
\hline \multicolumn{4}{|l|}{$\begin{array}{l}\text { Achievement Goals or } \\
\text { Reward-Oriented Goals }\end{array}$} \\
\hline $\begin{array}{l}\text { 7. Getting a good job in the } \\
\text { future. }\end{array}$ & $4.81(.67)$ & $4.64(.78)$ & $4.84^{*}$ \\
\hline $\begin{array}{l}\text { 8. Avoiding punishment (or } \\
\text { loss of privileges). }\end{array}$ & $4.23(.52)$ & $1.04(.53)$ & $36.48^{*}$ \\
\hline
\end{tabular}

Statistical Significance. ${ }^{*} p<0.05 ;{ }^{* *} p<0.0$ 
OF PSYCHOLOGY

IN THE $21^{\text {st }}$ CENTURY Volume 4, 2012

Table 6. Mean Difference in the Motivation Variable (Learning Goals) Based on the Performance Variable (Grades 7 to 10).

\begin{tabular}{|c|c|c|c|}
\hline & & & $\mathrm{gl}=540$ \\
\hline Goals & $\begin{array}{l}\text { Average Grades Between } \\
5 \text { and } 7^{*}(\mathrm{SD})\end{array}$ & $\begin{array}{l}\text { Average Grades Between } \\
7 \text { and } 10^{* *}(\mathrm{SD})\end{array}$ & $\mathrm{t}$ \\
\hline \multicolumn{4}{|l|}{ Learning Goals } \\
\hline $\begin{array}{l}\text { 1. Acquiring competence and } \\
\text { control. }\end{array}$ & $3.22(.72)$ & $4.68(.81)$ & $-13.59^{*}$ \\
\hline $\begin{array}{l}\text { 2. Interest in the subject } \\
\text { (intrinsic motivation). }\end{array}$ & $1.66(.23)$ & $3.62(.44)$ & $-17.81^{*}$ \\
\hline \multicolumn{4}{|l|}{ Self-Oriented Goals } \\
\hline $\begin{array}{l}\text { 3. Defense of the Self } \\
\text { by personal involvement } \\
\text { (promoting motivation). }\end{array}$ & $2.54(.80)$ & $4.24(.91)$ & $-15.64^{*}$ \\
\hline $\begin{array}{l}\text { 4. Defense of the Self } \\
\text { by lack of involvement } \\
\text { (motivational inhibition). }\end{array}$ & $2.13(.82)$ & $1.18(.89)$ & $10.76^{*}$ \\
\hline $\begin{array}{l}\text { 5. Self-aggrandizement (by } \\
\text { involvement). }\end{array}$ & $2.56(.19)$ & $3.05(.61)$ & $-8.00^{*}$ \\
\hline \multicolumn{4}{|l|}{ Socially-Oriented Goals } \\
\hline $\begin{array}{l}\text { 6. Acquiring social value } \\
\text { by getting approval or } \\
\text { by avoiding rejection } \\
\text { (involvement). }\end{array}$ & $2.25(.69)$ & $1.22(.71)$ & $10.24^{*}$ \\
\hline \multicolumn{4}{|l|}{$\begin{array}{l}\text { Achievement Goals or } \\
\text { Reward-Oriented Goals }\end{array}$} \\
\hline $\begin{array}{l}\text { 7. Getting a good job in the } \\
\text { future. }\end{array}$ & $3.78(.70)$ & $4.64(.78)$ & $-13.71^{*}$ \\
\hline $\begin{array}{l}\text { 8. Avoiding punishment (or } \\
\text { loss of privileges). }\end{array}$ & $2.14(.41)$ & $1.04(.53)$ & $10.63^{*}$ \\
\hline
\end{tabular}

Statistical Significance. ${ }^{*} p<0.05 ;{ }^{* *} p<0.0$

With regards to the motivation-performance comparison, results show that academic performance increases as learning goals increase. This means that students who achieve a good performance (i.e. high grades in EFL) are intrinsically motivated (i.e. their learning goals involve motivation, effort and persistence to tackle academic tasks in order to acquire competences). In other words, students who achieve high grades in EFL seek meaningful learning and reformulate their strategies when they encounter academic failure. Results show that students with learning and performance goals present significantly higher values as far as academic performance is concerned. On the other hand, students who have a fear of failure or socially-oriented goals (i.e. avoiding social rejection) present significantly lower values in academic performance as compared to other students. Likewise, students with less academic performance (i.e. low grades in EFL) have low scores in goals oriented to punishment-avoidance. This means that they are extrinsically motivated, i.e. they tackle the task in order to achieve a goal different from the task in itself (such as avoiding parents' punishment). It is also worth stressing that self-oriented goals based on the defense of the Self (which are the ones promoting motivation, as described in the Section "Types of Goals") achieve high scores in line with academic performance. Conversely, goals based on motivational inhibition are inversely proportional to academic performance. Equally, socially-oriented goals (described in Table 1) are inversely proportional to academic performance. This means that students' motivation for getting low grades is related to the acquisition of social value, either by getting approval and acceptance from others, or by avoiding social rejection. In other words, they aim to achieve good results in order to reinforce their 
social image. Additionally, they get frustrated with poor results, which would account for a type of extrinsic motivation. Conversely, students who get high grades are not motivated by goals such as Volume 4, 2012 getting approval from others, but their motivation comes from within, from the act of learning itself. In other words, these students show a predominance of learning goals (defined in Table 1).

\section{Discussion}

Learning goals can predict and control behaviour, which is relevant in view of analysing associations among motivation, learning and academic performance. In fact, recent researchers have stressed the importance of assessing multiple goals (both social and academic) with the purpose of achieving the socio-emotional and academic integration of secondary education students (GonzálezPienda, González-Cabanach, Núñez and Valle, 2002; Valle et al., 2008). In general terms, it can be stressed that the profile of the studied sample is characterized by the predominance of learning goals as well as reward-oriented goals. In other words, participating secondary education students study EFL either because they like the subject per se (hence they seek to improve their competence, i.e. they are intrinsically motivated), or because they seek to get a good job in the future (hence they seek a reward-oriented goal, i.e. they are extrinsically motivated).

With regards to reward-oriented goals, there is a clear difference as far as results are concerned: When motivation is based on punishment-avoidance or loss of privileges (extrinsic motivation), students get poorer results (less performance). This would confirm the working hypothesis of the study: the higher extrinsic motivation, the lower academic performance. These results are consistent with those shown by Valle et al. (2008), suggesting that avoidance goals are more maladaptive than learning and performance goals. However, within the same category, results show that students with both good and poor grades are equally motivated to get a good job in the future. This means that when motivation is understood as the effort and persistence to tackle academic tasks in order to get a job, it is equally important to the entire sample, as all boys and girls participating in this study have assigned a high score to the items reflecting it.

In line with what other authors have found in relation to other school subjects (GonzálezPineda et al., 2002; Valle et al., 2008; Valle et al., 2009), results derived from the context in which this study was conducted have shown that an association exists between learning goals and a high academic performance. On the other hand, students who have a fear of failure or socially-oriented goals present lower values in academic performance in the subject of EFL.

It is worth stressing that the different academic goals are not mutually exclusive. Especially relevant is the fact that, in all analysed cases, the existence of two motivational orientations has been confirmed: (1) intrinsic motivation and (2) extrinsic motivation. To this light, while some students are driven by a desire to master the task, curiosity, perception of the task as a challenge and interest to learn (intrinsic motivation), others are driven by the achievement of extrinsic goals (extrinsic motivation), such as getting good grades, rewards, favourable judgments, teachers' and parents' approval and avoidance of negative judgments (Dweck and Leggett, 1988; González-Pineda et al., 2002).

Most research on motivation and second language acquisition (Masgoret and Gardner, 2003) was conducted in Canada and the United States. In the Spanish context, further studies are still required in the area of English as a Foreign Language, in order to examine in depth the variables, using not only quantitative methods but also qualitative ones (interviews and observation). These methods would improve motivational techniques in the teaching/learning of English, hence increasing the level of English proficiency in Spain, which is below what is expected. In this sense, the present study is relevant to the teaching practice in the Spanish context, as the goal theory can provide a great amount of information on foreign language students' motivation, as well as on their ability to develop self-regulated learning, that is, a type of learning which, further from being considered a mere transfer of knowledge between teachers and students, requires the construction of knowledge by students themselves (Suárez and Fernández, 2004). Finally, as suggested by Núñez (2008), these studies can provide a more realistic line of research, involving different types of goals, not in an antagonistic way, but rather as complementary aims to which students can resort based on their personal interests and situational demands. 


\section{Conclusions}

To conclude, the present study has proven that there is a correlation between academic goals and academic results; in particular an association exists between learning goals (intrinsic motivation) and a high performance. In other words, learning goals are associated to a high use of processing strategies and to highly-qualified learning strategies, which facilitate the comprehension of the material to be learned. Along these lines, established studies (Valle et al., 2009) have found that the deep learning approach is related to students' involvement and intrinsic interest in learning in those students who attribute their academic results to internal causes, such as effort or capacity. While it is important for students to have learning goals, it is also worth stressing that performance goals do not have to be necessarily maladaptive, but they can coexist together with learning goals to allow students to achieve a good performance (Elliott and Dweck, 1988). Notably, Valle et al. (2009) found that secondary education students with an extrinsic motivation (recognition from others) can take responsibility for their success/failure and can also show learning goals. Furthermore, it can also be assumed that the combined use of the two types of goals has an enhanced effect and a multiplicative effect on performance. To achieve such effects, all the motivational resources suggested by the teacher can be helpful. It is also important to consider the fact, that the student might be extrinsically motivated does not exclude him/her from developing feelings of personal control and competences; neither does it from showing a positive performance. What this study has shown is the importance of intrinsic motivation (i.e. learning goals) in achieving good academic results; by showing that the best grades corresponded to learning goals.

These results may be taken into account in view of an education aimed to improve social coexistence and attention to motivational diversity, as students are not only different as far as knowledge, competences and attitudes are concerned, but they also differ at a motivational level. Therefore, there are undoubtedly different ways to approach learning and achieve academic success.

Finally, it is worth highlighting that the study has shown the relevant role that academic goals (i.e. learning goals, self-oriented goals, socially oriented goals and reward-oriented goals) play in predicting school behaviour. This study has direct implications for the psycho-educational assessment and intervention in the area of assessment and intervention of motivational components and academic performance in Secondary Education.

\section{Acknowledgements}

This study was funded by the Dirección General de Investigación (General Research Design). Spanish Ministry of Education and Science.

\section{References}

Ames, C. (1992). Classrooms: Goals, Structure, and Student Motivation. Journal of Educational Psychology, $84,261-271$.

Ames, C., Archer, J. (1988). Achievement Goals in the Classroom: Students' Learning Strategies and Motivation Processes. Journal of Educational Psychology, 80, 260-267.

De la Fuente, J. (2012). Procesos motivacionales en el aprendizaje escolar. [Motivational Processes in School Learning]. En M. V. Trianes (Coord.), Psicología del desarrollo y de la educación, pp. 247-264. [Developmental and Educational Psychology]. Madrid: Pirámide.

Dweck, C. S., Leggett, E. (1988). A Social-Cognitive Approach to Motivation and Personality. Psychological Review, 95, 256-273.

Elliott, E. S., Dweck, C. S. (1988). Goals: An Approach to Motivation and Achievement. Journal of Personality and Social Psychology, 54, 5-12.

García, T., Pintrich, P.R. (1994). Regulating motivation and cognition in the classroom: The role of self-schemas and self-regulatory strategies. En D. H. Schunk, B. J. Zimmerman (Eds.). Self-regulation of learning and performance. Issues and educational applications. Hillsdale, NJ.: LEA. 
González-Pineda, J. A; González-Cabanach, R., Núñez, J. C., Valle, A. (2002). Manual de psicología de la educación. [Educational Psychology]. Madrid: Pirámide.

Masgoret, A. M., Gardner, R. C. (2003). Attittudes, motivation and second language learning: a meta-analysis of studies conducted by Gardner and associates. Language Learning, 53, 167-210.

Nicholls, J. G. (1984). Achievement Motivation: Conceptions of Ability, Subjective Experience, Task Choice, and Performance. Psychological Review, 91, 328-346.

Núñez, J. C., González-Pienda, J. A., González-Pumariega, S, García, M., \& Roces, C. (1997). Cuestionario para la Evaluación de Metas Académicas en Secundaria (CEMA-II). [Questionnaire to Assess Academic Goals in Secondary Education Students (CEMA-II)]. Departamento de Psicología. Universidad de Oviedo.

Núñez, J. C. (2008). Aportaciones de la psicología educativa al proceso enseñanza-aprendizaje. [Contributions of Educational Psychology to the Teaching-Learning Process]. Oviedo: FOCAD.

Pekrun, R. (1992). The Impact of Emotions on Learning and Achievement: Towards a Theory of Cognitive/ Motivational Mediators. Applied Psychology: An International Review, 41, 4, 359-376.

Pintrich, P. R. (2000b). Multiple Goals, Multiple Pathways: The Role of Goal Orientation in Learning and Achievement. Journal of Educational Psychology, 92, 544-555.

Pintrich, P. R., De Groot, E.V. (1990). Motivational and Self-Regulated Learning Components of Classroom Performance. Journal of Educational Psychology, 82, 33-40.

Schunk, D. H. (2000). Learning Theories: An Educational Perspective. New Jersey: Prentice Hall.

Suárez, J. M., Fernández, A. P. (2004). El aprendizaje autorregulado: variables estratégicas, motivacionales, evaluación e intervención. [Self-regulated Learning: Strategical and Motivational Variables, Assessment and Intervention]. Madrid: UNED.

Valle, A., Cabanach, R. G., Rodríguez, S., Núñez, J., González-Pineda, J. A., Rosario, P. (2009). Perfiles motivacionales en estudiantes de Secundaria: Análisis diferencial en estrategias cognitivas, estrategias de autorregulación y rendimiento académico. [Middle School Students' motivational profiles: Analyzing the differences in cognitive strategies, self-regulated strategies and academic achievement]. Revista Mexicana de Psicología, 26 (1), 113-124.

Valle, A., Núñez, J. C., Cabanach, R. G., Rodríguez, S., González-Pineda, J. A., Rosario, P. (2008). Capacidad predictiva de las metas académicas sobre el rendimiento en diferentes áreas curriculares. [Academic goals and predictive power of the academic achievement in different school subjects of Spanish core curriculum]. Revista Latinoamericana de Psicología, 40, 111-122.

Wolters, C. (2004). Advancing achievement goal theory: Using goal structures and goal orientations to predict students motivation, cognition and achievement. Journal and Educational Psychology, 96, 236-250.

Advised by Guna Svence,

Riga Teacher Training and Educational Management Academy, Latvia

Received: September 24, 2012

Accepted: November 19, 2012

Francisco Manuel Morales Rodríguez
$\mathrm{PhD}$ in Psychology and Bachelor of Labour, Associate Professor (Doctor), Department of Psychology and Education, School of Psychology, University of Malaga, Campus de Teatinos s / n, 29071, Malaga, Spain.

E-mail: framorrod@uma.es

Website: http://webdeptos.uma.es/psicoev/ 